\title{
Potential of Local Entomopathogenic Nematodes for Control of the Vine Mealybug, Planococcus ficus
}

\author{
T. Platt ${ }^{1}$, N.F. Stokwe ${ }^{1,2}$, A.P. Malan ${ }^{1, *}$ \\ (1) Department of Conservation Ecology and Entomology, Stellenbosch University, Private Bag X1, Matieland 7602, South \\ Africa \\ (2) Agricultural Research Council (ARC) - Infruitec-Nietvoorbij, Private Bag X5026, Stellenbosch 7599, South Africa
}

Submitted for publication: January 2018

Accepted for publication: April 2018

Keywords: Grapevine, Heterorhabditidae, integrated pest management, mealybug, Planococcus ficus, Steinernematidae

\begin{abstract}
Planococcus ficus, the vine mealybug, is the dominant mealybug pest of grapes in South Africa. To provide an alternative for chemical control, entomopathogenic nematodes (EPNs) were investigated as a biological control agent to be used in an integrated pest management system. Four local EPN species were screened for efficacy against female $\boldsymbol{P}$. ficus, the most potent of which were Heterorhabditis noenieputensis, with $\mathbf{9 0 \%}$ mortality, and Steinernema yirgalemense, with $63 \%$. Since $S$. yirgalemense was previously shown to be highly effective against a range of pests, the effects of temperature and humidity on the infectivity of $S$. yirgalemense to female $P$. ficus were also assessed. The application of $S$. yirgalemense at $25^{\circ} \mathrm{C}$ yielded the highest mortality, of $72 \%$, followed by $45 \%$ mortality at $30^{\circ} \mathrm{C}$, and only $9 \%$ mortality when applied at $15^{\circ} \mathrm{C}$. Steinernema yirgalemense performed best at $100 \%$ relative humidity (RH), resulting in $70 \%$ mortality. Decreasing RH levels resulted in decreased mortality (61\% mortality at 80\% RH, $40 \%$ mortality at $60 \% \mathrm{RH}$ ). As a soil-based organism, $S$. yirgalemense is most effective as a biocontrol agent of $P$. ficus under conditions of moderate temperature and high humidity. Its lethality to $P$. ficus, and its status as an indigenous species, indicate its promise as a potential biocontrol agent of the vine mealybug.
\end{abstract}

\section{INTRODUCTION}

South Africa is a major global wine and table grape producer, exporting 428.4 million litres of wine products and 65.4 million cartons of table grapes in the 2017 season (South African Table Grape Industry [SATGI], 2017; South African Wine Industry Information and Systems [SAWIS], 2017). The vine mealybug, Planococcus ficus (Signoret), is the dominant mealybug pest of South African vineyards (Walton, 2003), and the major vector for grapevine leafroll- associated virus 3 (GLRaV-3) (Douglas \& Krüger, 2008). Mealybug nymphs and adult females feed on the phloem, which reduces vigour, and secrete honeydew, which encourages the growth of sooty mould that damages and disfigures the fruit (Daane et al., 2006). GLRaV-3 reduces grape yield and quality and vine longevity, and increases grapevine susceptibility to fungus infections and environmental changes (Cabaleiro et al., 2013).

Effective mealybug control is required to safeguard grape harvests and reduce the spread of GLRaV-3. Mealybugs produce the waxy, hydrophobic secretion that gives them their name, in addition to residing in cryptic habitats under the raised bark on the trunk of grapevines. Both these factors complicate the application of nonsystemic pesticides (Berlinger, 1977; Walton \& Pringle,
2004). Pesticides remain the dominant pest control method of $P$. ficus, although concern about the contamination of food chains, harm to non-target organisms (including natural enemies of the pest) and the development of resistance have prompted interest in non-chemical control methods such as biological control (Hussaini, 2002).

Entomopathogenic nematodes (EPNs) of the order Rhabditida prey exclusively on insects. EPNs of the families Steinernematidae and Heterorhabditidae, in particular, have been used as biocides against soil-based pests with great success (Campos-Herrera, 2015). Despite their genetic dissimilarity, the Heterorhabditid and Steinernematid families share many biological traits (Blaxter et al., 1998). EPNs exist in the soil in the free-living infective juvenile (IJ) stage. The IJs enter the body cavity of the insect host through natural openings, whereupon they release symbiotic bacteria from the gut that kill the insect via septicaemia (Adams \& Nguyen, 2002). The bacteria bioconvert the host's tissues, upon which IJs then feed and mature into the adult stage. After one or two generations, depending on the size of the host, when the food within the cadaver is depleted, thirdstage juveniles store a small amount of bacteria in their digestive system and moult into the pre-infective and IJ

*Corresponding author: E-mail address: apm@sun.ac.za

Acknowledgments: The authors would like to thank Winetech, the South African Table Grape Industry (SATGI), the Agricultural Research Council (ARC) and the Technology and Human Resources for Industry Programme (THRIP grant number: TP14062571871), for funding the project 
stages before leaving the host (Wright \& Perry, 2002).

EPNs, having proven attractive as potential biocontrol agents of insects, have been successfully commercialised for such use on four continents (Ehlers, 1996; Kaya et al., 2006). Their application has tended to focus on the soil-based stages in the life cycles of insect pests, as EPNs are adapted to soil environments (Wilson \& Gaugler, 2004), though EPNs have also been successfully used against tunnelling/boring pest insect life stages (Ehlers, 1996). Research on the application of EPNs for the control of foliage-based pest insect life stages has been rarer and less successful than that on soil application (Shapiro-Ilan et al., 2006; Platt, 2017).

EPNs possess traits that make them attractive as potential biocontrol agents of $P$. ficus. Whereas contact insecticides rely on direct application for efficacy, the active searching behaviour of some EPNs would allow them to seek out and find $P$. ficus individuals in their cryptic habitats after application onto foliage. It is also reasonable to assume that a foliage-adapted insect life stage would have no evolved defences against insect pathogens that occur in the soil. Gumus et al. (2015) assessed a method of introducing EPNs into insect pests in cryptic habitats, using pre-infected hosts as "living insect-bombs". They found that pre-infected goat moth larvae (Cossus cossus Linnaeus) (Lepidoptera: Cossidae) performed better in introducing Steinernema carpocapsae (Weiser, 1955) Wouts, Mráček, Gerdin and Bedding into cryptic habitats of the larval stage of the moth inside chestnut logs (86\% mortality) than spray application ( $<4 \%$ mortality). They also found that using pre-infested individuals of a lawn caterpillar species, Spodoptera cilium Guenée, (Lepidoptera: Noctuidae), was as effective as spray applications in controlling this insect on Bermuda grass.

EPNs are soil-adapted organisms, with the prevailing environmental conditions outside of the soil posing challenges to their survival and efficacy. They are sensitive to extremes of temperature (Grewal et al., 1994), relative humidity (\% RH) (Glazer, 1992) and ultraviolet radiation (UV) (Gaugler et al., 1992), with individual environmental requirements varying between species. However, the limitations can be manipulated; for example, nematode species can be applied in greenhouses where the temperature and humidity can be controlled, or applied to crops in the field at times of the day when the temperature and humidity most closely match the optimal conditions for the nematode species used. Additionally, adjuvants can be used as coformulants to change the properties of EPN treatments, e.g. to maintain higher RH. Adjuvants are defined as additives that can either augment or modify the effects of crop treatments (Krogh et al., 2003).

Previous research in South Africa on the control of mealybug include the work of Van Niekerk and Malan (2012), who assessed the efficacy of EPNs against the citrus mealybug, Planococcus citri (Risso). They found that both Steinernema yirgalemense Nguyen, Tesfamariam, Gozel, Gaugler and Adams, 2005 and Heterorhabditis zealandica Poinar, 1990 were able to infect and complete their life cycles in female $P$. citri. It was indicated that the first two to four hours after application were critical for optimal infection of $P$. citri, with humidity being the main limiting factor preventing IJs from surviving long enough to infect their host. Follow-up research by Van Niekerk and Malan (2013) found that the addition of spreader and sticker adjuvants increased both the pathogenicity of $H$. zealandica and the deposition of nematodes on leaves.

Stokwe and Malan (2016) tested EPNs for use against another South African mealybug pest, the obscure mealybug Pseudococcus viburni Signoret, which is a major pest of pome fruit. They found that EPNs (specifically $H$. zealandica and $S$. yirgalemense) were able to penetrate and complete their life cycle within adult $P$. viburni females. The ability of EPNs to penetrate cryptic habitats to infect their insect hosts was also demonstrated, with IJs of $H$. zealandica being able to enter infested apple cores in order to infect the $P$. viburni individuals within.

Le Vieux and Malan (2013) assessed the potential of EPNs in controlling the vine mealybug in South Africa. Eight EPN species, six of which are indigenous to South Africa, were screened for pathogenicity to local populations of $P$. ficus. Two indigenous species, $H$. zealandica and $S$. yirgalemense, proved to be the most effective. Later research by Le Vieux and Malan (2015) indicated that $S$. yirgalemense was capable of detecting $P$. ficus individuals and actively seeking out mealybug hosts to infect.

In this study, recently isolated EPN species were tested for their potential to control P. ficus under optimal laboratory conditions. As $S$. yirgalemense is currently being targeted

TABLE 1

Entomopathogenic nematodes (Steinernema and Heterorhabditis) used by species, isolate, habitat, locality, and GenBank accession number, noting the length and maximum body width of the infective juveniles.

\begin{tabular}{|c|c|c|c|c|c|c|}
\hline Species & Strain & Habitat & Locality & $\begin{array}{l}\text { Accession } \\
\text { number }\end{array}$ & Length of IJ $(\mu \mathrm{m})$ & Width of IJ $(\mu \mathrm{m})$ \\
\hline H. noenieputensis & SF669 & Fig tree & $\begin{array}{l}\text { Noenieput, } \\
\text { Northern Cape }\end{array}$ & JN620538 & $528(484-563)^{\mathrm{a}}$ & $21(19-23)^{\mathrm{a}}$ \\
\hline S. jeffreyense & J194 & Guava tree & $\begin{array}{l}\text { Jeffrey's Bay, } \\
\text { Eastern Cape }\end{array}$ & KC897093 & $924(784-1043)^{b}$ & $35(23-43)^{b}$ \\
\hline S. yirgalemense & $157-\mathrm{C}$ & Citrus orchard & $\begin{array}{l}\text { Friedenheim, } \\
\text { Mpumalanga }\end{array}$ & EU625295 & $635(548-693)^{\mathrm{c}}$ & $29(24-33)^{\mathrm{c}}$ \\
\hline S. litchii & WS9 & Litchi orchard & $\begin{array}{l}\text { Nelspruit, } \\
\text { Mpumalanga }\end{array}$ & KP325086 & $1054(953-1146)^{\mathrm{d}}$ & $35(29-41)^{\mathrm{d}}$ \\
\hline
\end{tabular}

${ }^{\mathrm{a}}$ Malan et al.,, 2014; ${ }^{\mathrm{b}}$ Malan et al., 2016; 'Malan et al., 2011; 'Steyn et al., 2017 
for mass culture, the potential for foliar application of this nematode in terms of infection rate, temperature and humidity was further investigated.

\section{MATERIALS AND METHODS \\ Source of nematodes}

The nematode species used in this study (Table 1) originated from soil samples collected locally and were maintained and cultured at Stellenbosch University. The nematodes were cultured in vivo using larvae of the mealworm, Tenebrio molitor L. (Coleoptera: Tenebrionidae). Inoculated mealworms were kept at $25^{\circ} \mathrm{C}$ until IJ emergence, before being transferred to modified White traps (Woodring \& Kaya, 1988). The IJs harvested from the White traps were transferred to vented culture flasks and stored at $14^{\circ} \mathrm{C}$, keeping within the guidelines set out by Kaya and Stock (1997). The flasks were gently agitated once a week to improve aeration, and the IJs were used within one week of emergence.

\section{Source of insects}

A laboratory culture of $P$. ficus was established to ensure reliable access to females. The culture originated at the Agricultural Research Council (ARC) Infruitec-Nietvoorbij in Stellenbosch, South Africa. Mealybugs were propagated on butternut squash (Cucurbita moschata Duchesne) in a Perspex cage, under ambient conditions. The cage was vented with mesh netting to allow for air circulation, but otherwise kept sealed to prevent the escape of crawlers. A fresh butternut was added once every three weeks, allowing the individuals to migrate from the older butternut, which was then removed once rot began to set in. Female mealybugs were handled with a small paintbrush. Individuals were removed only if they were not feeding, as damage to mouthparts can negatively affect the insect's survival.

\section{Pathogenicity and penetration}

A 24-well bioassay tray was used as the test arena for inoculating mealybugs with EPN species. A $13 \mathrm{~mm}$ diameter piece of filter paper was added to twelve alternate wells to absorb excess liquid. One female P. ficus was added to each filter paper-lined well, for a total of 12 individuals per tray. Each mealybug was treated with 100 IJs suspended in $50 \mu \mathrm{l}$ of water, which was applied directly to the filter paper of each well using a pipette, while the control trays received water only. The trays were covered with a glass cover to prevent the insects escaping. The lid was placed onto the bioassay tray and secured with an elastic band. One tray represented a single replicate. Five replicates (with 60 insects per treatment) were enclosed in $2 \mathrm{~L}$ plastic containers lined with moist paper towels to maintain humidity levels of $>95 \%$. The containers were kept in growth chambers at $25^{\circ} \mathrm{C}$ for $48 \mathrm{~h}$, after which each mealybug was removed, washed and placed into Petri dishes lined with moistened pieces of filter paper. The Petri dishes were sealed with Parafilm and incubated at $25^{\circ} \mathrm{C}$ for another $48 \mathrm{~h}$, to allow nematode development to take place inside the insects. Mortality caused by infection was visually confirmed by dissection with the aid of a dissection microscope (Leica MZ7s).
The bioassay protocol described above was used to determine the pathogenicity of the species indicated in Table 1 (including three newly described EPN species) against $P$. ficus, compared to a known species, $S$. yirgalemense. Mealybug mortality was assessed after $48 \mathrm{~h}$, with mortality defined as a lack of movement under the exertion of light external pressure, and a change from the mealybug's normal colour. The experiment was repeated on a later date with a fresh batch of nematodes.

\section{Infection rate}

Five Petri dishes (of $9 \mathrm{~cm}$ diameter) were lined with filter paper, and six female mealybugs were placed in each. Nematodes were applied in $1 \mathrm{ml}$ of water, containing 800 IJs of $S$. yirgalemense. Steinernema yirgalemense was selected for further study, as it was indicated in previous studies to be highly effective against codling moth (De Waal et al., 2011; Odendaal et al., 2016) and false codling moth (Malan et al., 2011), and is currently being targeted for mass culture. Each dish was sealed with Parafilm and placed in an incubator at $25^{\circ} \mathrm{C}$. Mealybugs from each of the five treatments were removed from the Petri dish after 30,60, 180, 240 or 480 min, rinsed with water, and then placed in a clean Petri dish lined with a piece of moistened filter paper. The Petri dishes were then sealed with Parafilm and returned to the incubator for $48 \mathrm{~h}$, after which mealybug mortality due to infection was confirmed by means of dissection.

\section{Effect of temperature}

The effect of different temperatures on the mortality of female $P$. ficus treated with $S$. yirgalemense was assessed. Five 24-well bioassay plates were prepared per temperature treatment, as previously described. Steinernema yirgalemense IJs were applied to each individual at a concentration of 100 IJs/50 $\mu$ l. One container (five 24 -well bioassay plates; 60 insects) was placed inside an incubator at $15^{\circ} \mathrm{C}, 25^{\circ} \mathrm{C}$ and $30^{\circ} \mathrm{C}$ respectively. After $48 \mathrm{~h}$, the mealybugs were assessed for mortality, which was confirmed by dissection. The experiment was repeated on a different test date with a fresh batch of nematodes.

\section{Effect of humidity}

The effect of different levels of humidity on the mortality of female $P$. ficus individuals treated with $S$. yirgalemense was assessed. Three plastic containers $(60 \times 120 \times 20 \mathrm{~cm})$ were prepared with $250 \mathrm{ml}$ glycerol $(80 \% \mathrm{RH}), \mathrm{KNO}_{3}$ salts (a $250 \mathrm{ml}$ saturated water solution) $(80 \% \mathrm{RH})$, and moistened tissue paper (100\% RH) (Winston \& Bates, 1960). Five 24well bioassay plates were prepared per humidity treatment, as previously described, while the control wells received water only. Steinernema yirgalemense was applied at a concentration of $100 \mathrm{IJS} / 50 \mu \mathrm{l}$. Rather than sealing with a lid, gauze netting was glued to the surface of each plate. Plates were then placed inside the prepared containers, which were placed inside an incubator at $25^{\circ} \mathrm{C}$. After $48 \mathrm{~h}$, the bioassay plates were removed from the containers and the mealybugs were assessed for mortality, which was confirmed by dissection. The experiment was repeated on a different test date with a fresh batch of nematodes. 


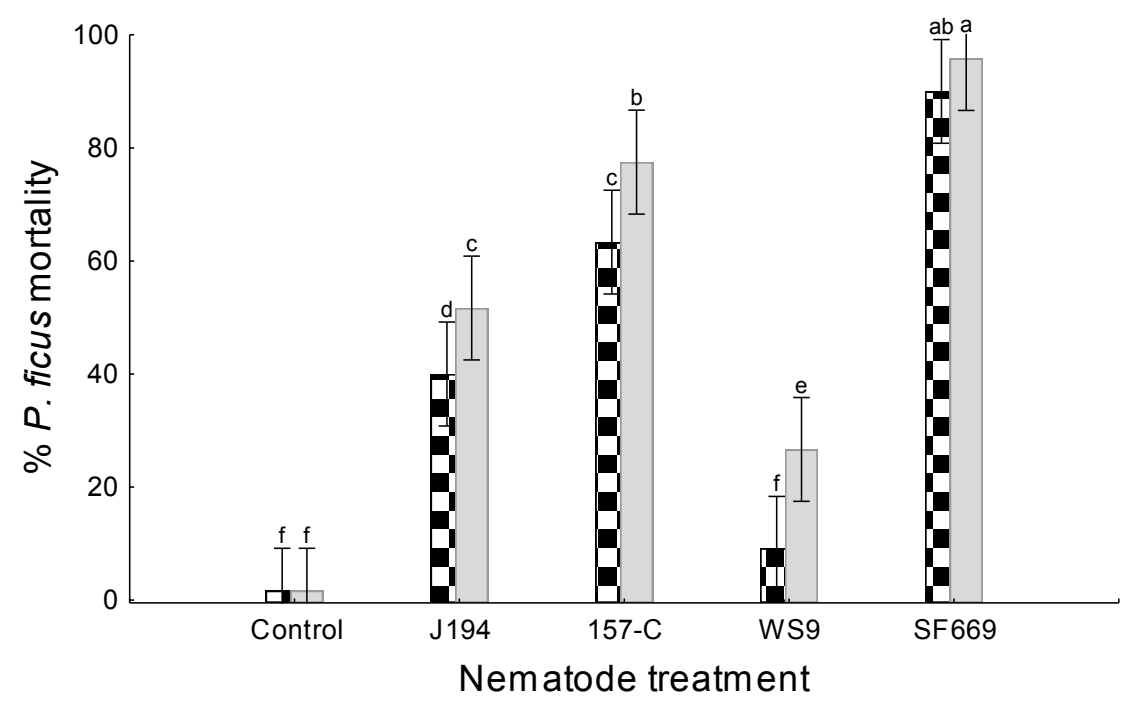

FIGURE 1

Mean percentage (95\% confidence interval) mortality of female Planococcus ficus, 48 h ( $\mathbf{E}$ ) and 96 h ( $\square$ ) post-treatment, using Steinernema jeffreyense (J194), Steinernema yirgalemense (157-C), Steinernema litchii (WS9), and Heterorhabditis noenieputensis (SF669). Infective juveniles (IJ) were applied to P. ficus at a concentration of $100 \mathrm{IJs} / \mathrm{insect}$ and kept at $25^{\circ} \mathrm{C}$ (one-way ANOVA: $\mathrm{F}_{(4,50)}=5.818 ; \rho<0.005$ ). The means of bars sharing the same letter are not significantly different from each another.

\section{Data analysis}

STATISTICA statistical analysis software, version 13 (TIBCO Software Inc., 2017), was used to establish the variance estimation, precision and comparison (VEPAC), and for the analysis of variance (ANOVA). The method of Bonferroni was employed for the post hoc comparison of means, with significant differences being calculated to the $95 \%$ probability level. If no significant difference was found between the main effects of treatments and the test date, the data from the two experiments were pooled.

\section{RESULTS}

\section{Pathogenicity and penetration}

A VEPAC analysis of the mortality caused by the four EPN species showed a significant difference between species $\left(\mathrm{F}_{(4,50)}=5.8179, \mathrm{p}=<0.01\right)$ (Fig. 1). Heterorhabditis noenieputensis caused $90 \% \pm 3 \%$ mortality of female $P$. ficus, which was significantly higher than for the other three species. The next most effective was $S$. yirgalemense $(63 \%$ $\pm 7 \%$ ), followed by $S$. jeffreyense $(40 \% \pm 7 \%)$. Mortality caused by Steinernema litchii $(9 \% \pm 4 \%)$ proved not to be significantly different from the control $(2 \% \pm 1 \%)$ (Fig. 1). Higher mortality was recorded after 96 h, but it did not differ significantly from the mortality obtained for $48 \mathrm{~h}$, except in the case of $S$. litchii $(\mathrm{p}<0.05)$.

The analysis of the penetration rate of IJs into P. ficus, using a one-way ANOVA, showed that significantly lower numbers of $S$. litchii were found in mealybug cadavers compared to all other species $\left(\mathrm{F}_{(3,150)}=3.4822, \mathrm{p}=<0.01\right)$. No significant difference was observed in the penetration levels of $S$. jeffreyense, S. yirgalemense and H. noenieputensis (Fig. 2).

\section{Infection rate}

The infection of $P$. ficus females after exposure to S. yirgalemense for $30 \mathrm{~min}$ was $10 \% \pm 7 \%$, and this increased significantly with increasing exposure time up to $3 \mathrm{~h}$. Mortality peaked at $40 \%$ to $60 \%$ after $8 \mathrm{~h}$ exposure time, but it did not differ significantly between the exposure times of 3,4 and $8 \mathrm{~h}\left(\mathrm{~F}_{(4,40)}=3.4265 ; \mathrm{p}=0.02\right)($ Fig. 3).

\section{Effect of temperature}

A factorial ANOVA was used to compare the results of $S$. yirgalemense infection of $P$. ficus at different temperatures. The difference in mealybug mortality between the different temperatures was shown to be significant $\left(\mathrm{F}_{(2,48)}=96.274\right.$; $\mathrm{p}<0.01)$. Mealybugs kept at $25^{\circ} \mathrm{C}$ resulted in the highest mortality $(72 \% \pm 3 \%)$, followed by those kept at $30^{\circ} \mathrm{C}(45 \%$ $\pm 3 \%$ ). Mealybugs treated with nematodes and kept at $15^{\circ} \mathrm{C}$ for $48 \mathrm{~h}$ resulted in the lowest mortality $(9 \% \pm 3 \%)$ (Fig. 4).

\section{Effect of humidity}

A factorial ANOVA of female $P$. ficus inoculated with $S$. yirgalemense indicated a significant difference in the ability of $S$. yirgalemense to cause mortality in $P$. ficus when kept at different levels of RH $\left(\mathrm{F}_{(2,53)}=32.433 ; \mathrm{p}=<0.01\right)$. Steinernema yirgalemense was most effective at $60 \% \mathrm{RH}$ $(40 \% \pm 3 \%)$, followed by $80 \% \mathrm{RH}(61 \% \pm 3 \%)$ and $100 \%$ RH $(70 \% \pm 3 \%)$ (Fig. 5).

\section{DISCUSSION}

Soil-based application of EPNs for the control of insect pests is logical, and effective EPN products are commercially available for the control of such soil-based life stages of insect pests. Foliar application of EPNs is desirable, because they have high pathogenicity to above-ground insects, 


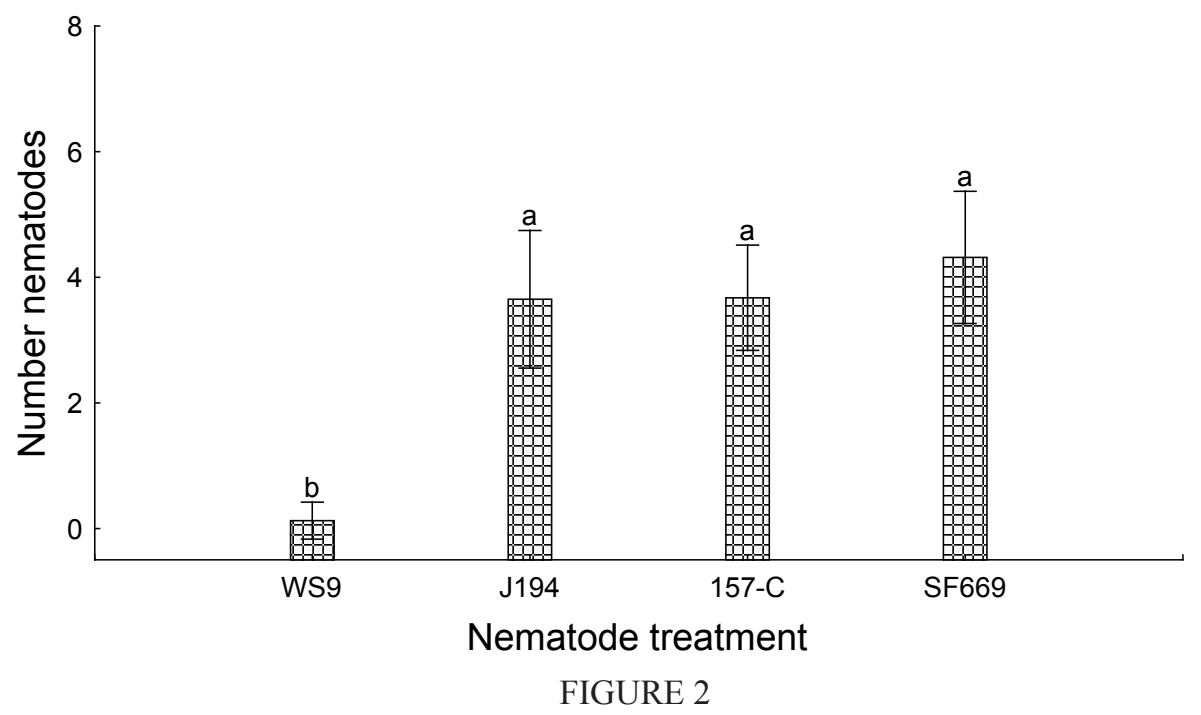

The mean number of nematodes (95\% confidence interval) found within the cadaver of female Planococcus ficus after $48 \mathrm{~h}$ exposure to Steinernema litchii (WS9), Steinernema jeffreyense (J194), Steinernema yirgalemense (157-C), and Heterorhabditis noenieputensis (SF669) (one-way ANOVA: $\mathrm{F}_{(3,150)}=3.482 ; \rho=0.017$ ). The means of bars sharing the same letter are not significantly different from each other.

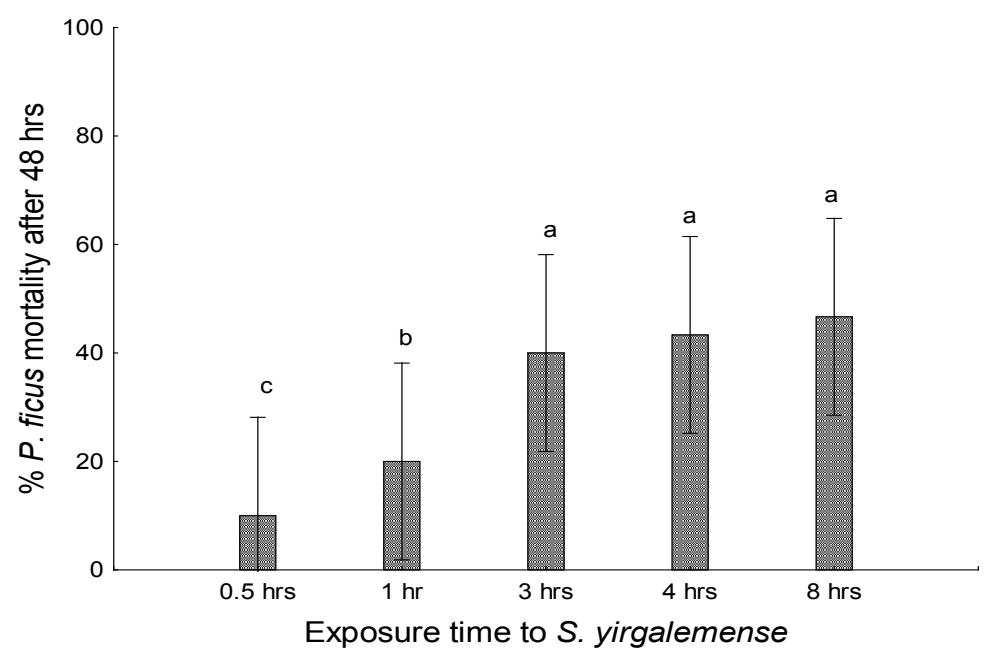

FIGURE 3

Mean percentage (95\% confidence interval) mortality of female Planococcus ficus determined 48 h after exposure to Steinernema yirgalemense for different time intervals, at a concentration of 133 infective juveniles (IJs)/insect. The means of bars sharing the same letter are not significantly different.

and their ability to seek out prey distinguishes them from chemical pesticides. Different EPN species also exhibit different levels of virulence to different insects, as each has its own specific characteristics. Consequently, since EPNs are not adapted specifically to above-ground insect pests, it is important to identify which EPN species are the most suitable for use against each insect pest.

Heterorhabditis noenieputensis was shown to be the most effective against female $P$. ficus, causing mortality of $>90 \%$ under ideal laboratory conditions. Steinernema yirgalemense was the next most effective, causing mortality of $63 \%$. This is in keeping with an earlier study by Le Vieux and Malan (2013), in which eight EPN species, six indigenous to South Africa and two commercially available species, namely
S. feltiae and H. bacteriophora, were screened for their ability to cause mortality in female P. ficus. The two most effective species were $H$. zealandica and $S$. yirgalemense. Van Niekerk and Malan (2012) also screened six indigenous EPN species for pathogenicity to $P$. citri, finding $H$. zealandica and $S$. yirgalemense to be the most effective. In this study, $S$. yirgalemense was selected for further testing, as other studies have also proven this species to be the most effective against codling (De Waal et al. 2011; Odendaal et al. 2016) and false codling moth (Malan \& Moore, 2016), with the potential to be mass cultured (Ferreira et al., 2016). However, should the mass-culture methods for heterorhabditid species being developed in South Africa succeed, H. noenieputensis would be an excellent candidate for the control of $P$. ficus. 


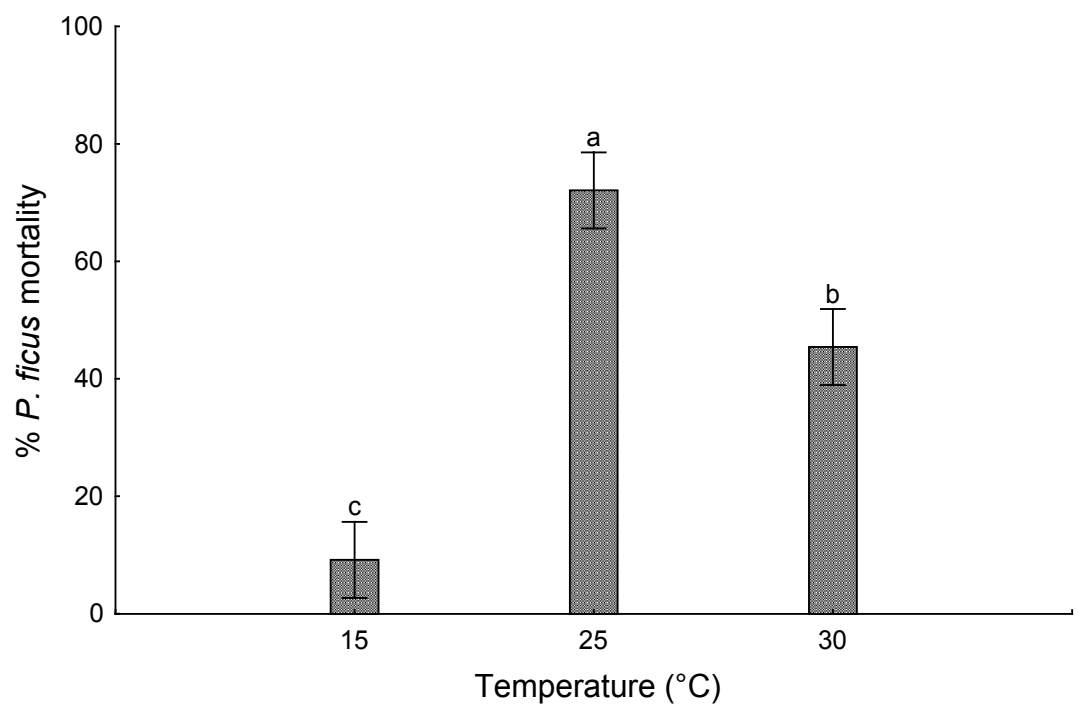

FIGURE 4

Mean percentage (95\% confidence interval) mortality for female Planococcus ficus after exposure to Steinernema yirgalemense at different temperatures. Infective juveniles (IJs) were applied at a concentration of $100 \mathrm{IJ} / 50 \mu \mathrm{l}$, and P. ficus was assessed for mortality after $48 \mathrm{~h}$. The means of bars sharing the same letter are not significantly different.

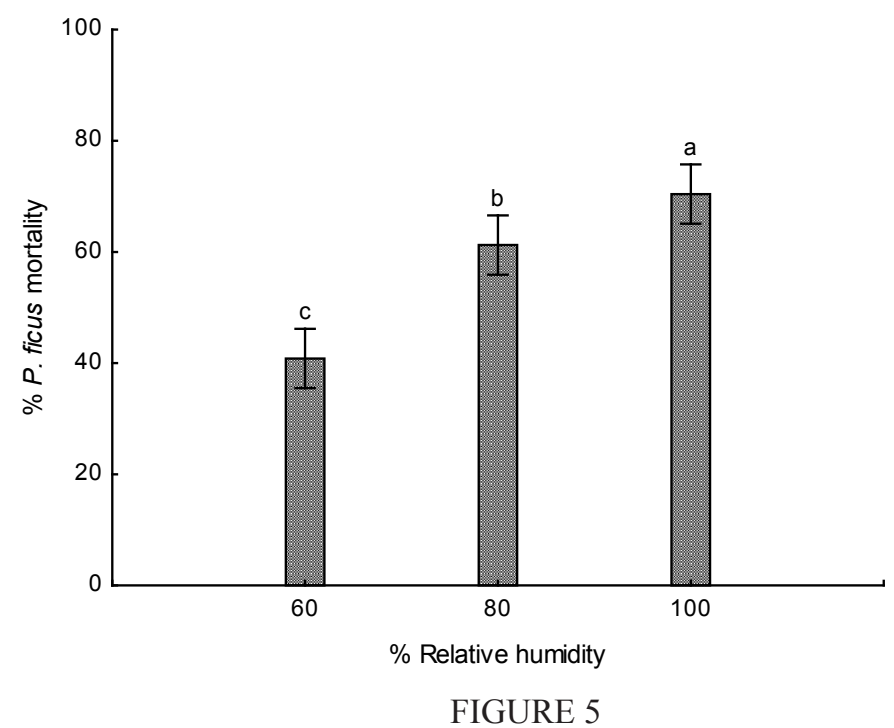

Mean percentage ( $95 \%$ confidence interval) mortality for female Planococcus ficus after exposure to Steinernema yirgalemense at different levels of relative humidity. IJs were applied at a concentration of $100 \mathrm{IJs} / 50 \mu 1$, and P. ficus was assessed for mortality after $48 \mathrm{~h}$. The means of bars sharing the same letter are not significantly different.

No significant difference was observed in the number of IJs of S. yirgalemense, $H$. noenieputensis and S. jeffreyense present in the infected cadavers, though the presence of each was significantly higher than that of S. litchii. One contributing factor to the differences in their penetration ability may be the difference in size of the IJs of each species (Nguyen \& Smart, 1995), since the IJs of S. litchii were both longer (1 $054 \mu \mathrm{m}$, on average) and wider $(35 \mu \mathrm{m})$ than those of S. yirgalemense or H. noenieputensis. Previous studies have compared the pathogenicity of one EPN species to different life stages (and therefore sizes) of the obscure mealybug $P$. viburni, finding that the smaller-bodied life stages were less susceptible to IJ infection than the adults
(Stokwe, 2009). However, as IJs of S. litchii are comparable in size to $S$. jeffreyense, size cannot be the only factor at play, indicating that more research is required on the infection mechanisms of these species.

This study has shown that $S$. yirgalemense was able to cause mortality in P. ficus after an exposure time of only $30 \mathrm{~min}$. It also showed that exposure to $S$. yirgalemense for longer than $3 \mathrm{~h}$ did not significantly improve mortality. This is comparable to the optimal time-to-mortality rate of S. yirgalemense against $P$. citri at $120 \mathrm{~min}$ (Van Niekerk \& Malan, 2013). These results indicate that the method of applying $S$. yirgalemense to grapevine foliage for the control of P. ficus should aim to preserve optimum conditions for 
activity, mobility and infectivity for at least $3 \mathrm{~h}$.

EPNs are highly sensitive to temperature, with each species possessing different optimal temperature niches for optimal IJ activity (Grewal et al., 1994), due to the negative effect that high temperatures have on oxygen in solution (Wright et al., 2005). Steinernema yirgalemense IJs were found to cause the highest mortality in P. ficus at $25^{\circ} \mathrm{C}$, followed by $30^{\circ} \mathrm{C}$, with the mealybugs incubated at $15^{\circ} \mathrm{C}$ showing the lowest overall mortality. This finding is in contrast with those of Van Niekerk and Malan (2013), who observed no significant difference in $H$. zealandica efficacy when applied to $P$. citri and incubated at $15^{\circ} \mathrm{C}, 20^{\circ} \mathrm{C}$ and $25^{\circ} \mathrm{C}$. Compared to $H$. zealandica, it can be inferred that $S$. yirgalemense is less tolerant of lower temperatures, showing much better performance against $P$. ficus at $25^{\circ} \mathrm{C}$ and $30^{\circ} \mathrm{C}$ than at $15^{\circ} \mathrm{C}$.

EPNs are soil-adapted and consequently require high levels of relative humidity in order to infect their hosts (Lacey \& Unruh, 1998), and a thin film of water to enable movement (Wright et al., 2005). In the current study, S. yirgalemense was found to be the most effective against $P$. ficus at $100 \% \mathrm{RH}$, resulting in $70 \%$ mealybug mortality. This was significantly higher than mortality at the lower percentage of RH. The finding concurs with those of previous studies on $P$. citri (Van Niekerk \& Malan, 2013), which tested S. yirgalemense and $H$. zealandica against the citrus mealybug at different water activity $\left(\mathrm{a}_{\mathrm{w}}\right)$ levels (roughly equivalent to \% $\mathrm{RH}$ ). Both the current study and the study by Van Niekerk and Malan (2013) clearly illustrate that $S$. yirgalemense performs best at maximum moisture levels.

From the present study it can be concluded that both $H$. noenieputensis and $S$. yirgalemense are promising indigenous EPN candidates for the control of P. ficus on foliage. Steinernema yirgalemense is the most attractive candidate for future work, as in vitro mass liquid culture of this species is currently being developed in South Africa. Future research will focus on attempts to mitigate the environmental weaknesses of $S$. yirgalemense on foliage, such as formulation with adjuvants to mitigate its intolerance to extremes of temperature and low humidity. This will prolong persistence on foliage to enable the nematode to locate and infect female $P$. ficus. The focus of future work should remain on the period between application and infection, as EPNs do not require assistance to survive within the mealybug once infection has taken place.

\section{LITERATURE CITED}

Adams, B.J. \& Nguyen, K.B., 2002. Taxonomy and systematics. In: Gaugler, R. (ed). Entomopathogenic nematology. CAB International, Wallingford. pp. $57-74$.

Berlinger, M.J., 1977. The Mediterranean vine mealybug and its natural enemies in southern Israel. Phytoparasitica 5, 3-14.

Blaxter, M.L., De Ley, P., Garey, J.R., Liu, L.X., Scheldeman, P., Vierstraete, A., Vanfleteren, J.R., Mackey, L.Y., Dorris, M., Frisse, L.M., Vida, J.T. \& Thomas, W.K., 1998. A molecular evolutionary framework for the phylum Nematoda. Nature 392, 71-75. doi:10.1038/32160

Cabaleiro, C., Pesqueira, A.M., Barrasa, M. \& Garcia-Berrios, J.J., 2013. Analysis of the losses due to grapevine leafroll disease in Albariño vineyards in Rías Baixas (Spain). Ciência e Técnica Vitivinícola 28, 43-50.
Campos-Herrera, R., 2015. Nematode pathogenesis of insects and other pests: Ecology and applied technologies for sustainable plant and crop protection. Springer International Publishing, Basel.

Daane, K.M., Bentley, W.J., Walton, V.M., Malakar-Kuenen, R., Millar, J.G., Ingels, C.A., Weber, E.A. \& Gispert, C., 2006. New controls investigated for vine mealybug. Calif. Agric. 60, 31-38. doi:10.3733/ca.v060n01p31

De Waal, J.Y., Malan. A.P. \& Addison, M.F., 2011. Efficacy of entomopathogenic nematodes (Rhabditida: Heterorhabditidae and Steinernematidae) against codling moth, Cydia pomonella (Lepidoptera: Tortricidae) in temperate regions. Biocont. Sci. Technol. 20, 489-502. doi: 1 $0.1080 / 09583157.2011 .607922$

Douglas, N. \& Krüger, K., 2008. Transmission efficiency of grapevine leafroll-associated virus 3 (GLRaV-3) by the mealybugs Planococcus ficus and Pseudococcus longispinus (Hemiptera: Pseudococcidae). Eur. J. Plant Pathol. 122, 201-212. doi:10.1007/s10658-008-9269-2

Ehlers, R.-U., 1996. Current and future use of nematodes in biocontrol: Practice and commercial aspects with regard to regulatory policy issues. Biocontrol Sci. Techn. 6, 303-316. doi:10.1080/09583159631299

Ferreira, T., Addison, M.F. \& Malan, A.P., 2016. Development and population dynamics of Steinernema yirgalemense and growth characteristics of its associated Xenorhabdus symbiont in liquid culture. J. Helminth. 90, 108112. doi:10.1017/S0022149X15000450

Gaugler, R., Bednarek, A. \& Campbell, J.F., 1992. Ultraviolet inactivation of heterorhabditid and steinernematid nematodes. J. Invertebr. Pathol. 160, 155-160. doi:10.1016/0022-2011(92)90026-Z

Glazer, I., 1992. Survival and efficacy of Steinernema carpocapsae in an exposed environment. Biocontrol Sci. Techn. 2, 101-107. doi:10.1080/09583159209355223

Grewal, P.S., Selvan, S. \& Gaugler, R., 1994. Thermal adaptation of entomopathogenic nematodes: Niche breadth for infection, establishment, and reproduction. J. Therm. Biol. 19, 245-253. doi:10.1016/03064565(94)90047-7

Gumus, A., Karagoz, M., Shapiro-Ilan, D. \& Hazir, S., 2015. A novel approach to biocontrol: Release of live insect hosts pre-infected with entomopathogenic nematodes. J. Invert. Pathol. 130, 56-60. doi:10.1016/j. jip.2015.07.002

Hussaini, S.S., 2002. Entomopathogenic nematodes for the control of crop pests. In: Upadhyay, R.K. (ed). Advances in microbial control of insect pests. Kluwer Academic/Plenum, Dordrecht. pp. 265 - 296.

Kaya, H.K., Aguillera, M.M., Alumi, A., Choo, H.Y., De la Torre, M., Fodor, A., Ganguly, S., Hazir, S., Lakatos, T., Pye, A., Wilson, M., Yamanaka, S., Yang, H. \& Ehlers, R.-U., 2006. Status of entomopathogenic nematodes and their symbiotic bacteria from selected countries or regions of the world. Biol. Control. 38, 134-155. doi:10.1016/j.biocontrol.2005.11.004

Kaya, H.K. \& Stock, S.P., 1997. Techniques in insect nematology. In: Lacey, L.A. (ed). Manual of techniques in insect pathology. Academic Press, London. pp. $281-324$.

Krogh, K.A., Halling-Sørensen, B., Mogensen, B.B. \& Vejrup, K.V., 2003. Environmental properties and effects of nonionic surfactant adjuvants in pesticides: A review. Chemosphere 50, 871-901. doi:10.1016/S00456535(02)00648-3

Lacey, L.A. \& Unruh, T.R., 1998. Entomopathogenic nematodes for control of codling moth, Cydia pomonella (Lepidoptera: Tortricidae) in fruit bins. J. Econ. Entomol. 6, 1863-1869. doi:10.1006/bcon.1998.0658

Le Vieux, P.D. \& Malan, A.P., 2013. The potential use of entomopathogenic nematodes to control Planococcus ficus (Signoret) (Hemiptera: Pseucoccidae). S. Afr. J. Enol. Vitic. 34, 296-306. 
Le Vieux, P.D. \& Malan, A.P., 2015. Prospects for using entomopathogenic nematodes to control the vine mealybug, Planococcus ficus, in South African vineyards. S. Afr. J. Enol. Vitic. 36, 59-70.

Malan, A.P. \& Moore, S.D., 2016. Evaluation of local entomopathogenic nematodes for the control of false codling moth, Thaumatotibia leucotreta (Meyrick, 1913), in a citrus orchard in South Africa. Afr. Entomol. 24, 489501. doi:http://dx.doi.org/10.4001/003.024.0489

Malan, A.P., Knoetze R. \& Moore, S.D., 2011. Isolation and identification of entomopathogenic nematodes from citrus orchards in South Africa and their biocontrol potential against false codling moth. J. Invert. Path. 108, 115-125. doi:10.1016/j.jip.2011.07.006

Malan, A.P, Knoetze, R. \& Tiedt, L.R., 2014. Heterorhabditis noenieputensis n. sp. (Rhabditida: Heterorhabditidae), a new entomopathogenic nematode from South Africa. J. Helminth. 88 (2), 139151. doi:10.1017/=S0022149X12000806

Malan, A.P., Knoetze, R. \& Tiedt, L.R., 2016. Steinernema jeffreyense n. sp. (Rhabditida: Steinernematidae), a new entomopathogenic nematode from South Africa. J. Helminth. 90, 262-278. doi:10.1017/S0022149X15000097

Nguyen, K.B. \& Smart, G.C., 1995. Scanning electron microscope studies of Steinernema glaseri (Nematoda: Steinernematidae). Nematologica 41, 183-190. doi:10.1163/003925995X00152

Odendaal, D., Addison, M.F. \& Malan, A.P., 2016. Evaluation of aboveground application of entomopathogenic nematodes for the control of diapausing codling moth (Cydia pomonella L.) under natural conditions. Afr. Entomol. 24, 61-74.

Platt, T., 2017. Investigating the above-ground application of entomopathogenic nematodes for the control of the vine mealybug, Planococcus ficus. MSc thesis, Stellenbosch University, Private Bag X1, 7602 Matieland (Stellenbosch), South Africa.

Shapiro-Ilan, D.I., Gouge, D.H., Piggott, S.J. \& Fife, J.P., 2006. Application technology and environmental considerations for use of entomopathogenic nematodes in biological control. Biol. Control 38, 124-133. doi:10.1016/j. biocontrol.2005.09.005

South African Table Grape Industry (SATGI), 2017. Statistics Booklet. SATGI, Paarl.

South African Wine Industry Information and Systems (SAWIS), 2016. South African Wine Industry Statistics. SAWIS, Paarl.

Steyn, W.P., Malan, A.P., Daneel, M.S. \& Slabbert, R.M., 2017. Entomopathogenic nematodes from north-eastern South Africa and their virulence against the false codling moth, Thaumatotibia leucotreta (Lepidoptera: Tortricidae). Biocont. Sci. Technol. 27(11). doi.org/10.1080 /09583157.2017.1391174
Stokwe, N.F., 2009. Entomopathogenic nematodes: Characterization of a new species, long-term storage and control of obscure mealybug, Pseudococcus viburni (Hemiptera: Pseudococcidae) under laboratory conditions. Thesis, Stellenbosch University, Private Bag X1, 7602 Matieland (Stellenbosch), South Africa.

Stokwe, N.F. \& Malan, A.P., 2016. Susceptibility of the obscure mealybug, Pseudococcus viburni (Signoret) (Pseudococcidae), to South African isolates of entomopathogenic nematodes. Int. J. Pest Manage. 62, 119-128. doi:10.1080/09670874.2015.1122250

TIBCO Software Inc., 2017. STATISTICA (data analysis software) version 13 . http://statistica.io

Van Niekerk, S. \& Malan, A.P., 2012. Potential of South African entomopathogenic nematodes (Heterorhabditidae and Steinernematidae) for control of the citrus mealybug, Planococcus citri (Pseudococcidae). J. Invertebr. Pathol. 111, 166-174. doi:10.7287/peerj.preprints

Van Niekerk, S. \& Malan, A.P., 2013. Adjuvants to improve aerial control of the citrus mealybug Planococcus citri (Hemiptera: Pseudococcidae) using entomopathogenic nematodes. J. Helminthol. 89, 189-195. doi:10.1017/ S0022149X13000771

Walton, V.M., 2003. Development of an integrated pest management system for vine mealybug, Planococcus ficus (Signoret), in vineyards in the Western Cape province, South Africa. Thesis, Stellenbosch University, Private Bag X1, 7602 Matieland (Stellenbosch), South Africa.

Walton, V.M. \& Pringle, K.L., 2004. Vine mealybug, Planococcus ficus (Signoret) (Hemiptera: Pseudococcidae), a key pest in South African vineyards: A review. S. Afr. J. Enol. Vitic. 25, 54-62. doi:10.21548/25-22140

Wilson, M. \& Gaugler, R., 2004. Factors limiting short-term persistence of entomopathogenic nematodes. J. Appl. Entomol. 128, 250-253. doi:10.1111/ j.1439-0418.2004.00814.x

Winston, P.W. \& Bates, D.H., 1960. Saturated solutions for the control of humidity in biological research. Ecology 41, 232-237

Woodring, J.L. \& Kaya, H.K., 1988. Steinernematid and Heterorhabditid nematodes: A handbook of techniques. Arkansas Agricultural Experimental Station (Southern Cooperative Series Bulletin 331), Fayetteville, Arkansas.

Wright, D.J. \& Perry, R.N., 2002. Physiology and biochemistry. In: Gaugler, R. (ed). Entomopathogenic nematology. CAB International, Wallingford. pp. $57-74$.

Wright, D.J., Peters, A., Schroer, S. \& Fife, J.P., 2005. Application technology. In: Grewal, P.S., Ehlers, R.U. \& Shapiro-Ilan, D.I. (eds). Nematodes as biocontrol agents. CAB International, Wallingford. pp. $91-106$. 